\title{
Hubungan Antara Dukungan Sosial dengan Kualitas Hidup pada Orang Dengan HIV dan AIDS (ODHA) Di Yayasan Spirit Paramacitta
}

\author{
Komang Diatmi dan I. G. A. Diah Fridari \\ Program Studi Psikologi, Fakultas Kedokteran, Universitas Udayana \\ mangdiatmi@gmail.com
}

\begin{abstract}
Abstrak
Orang yang telah terinfeksi virus HIV ini akan sangat rentan terserang penyakit, akibat rusaknya sistem kekebalan tubuh. ODHA dalam kesehariannya dituntut untuk mampu menghadapi permasalahan yang cukup kompleks. ODHA tidak hanya dihadapkan pada permasalahan dari sisi fisiologis akibat terinfeksi HIV, tetapi ODHA juga dihadapkan pada adanya stigma dan diskriminasi yang dapat menambah beban psikologis dari ODHA itu sendiri. Kompleksnya permasalahan yang mesti dihadapi oleh ODHA ini tentunya dapat berimbas pada penurunan kualitas hidup. Salah satu faktor yang memiliki peranan penting dalam kualitas hidup ODHA adalah dukungan sosial. Berdasarkan latar belakang tersebut, penelitian ini bertujuan untuk mengetahui hubungan antara dukungan sosial dengan kualitas hidup pada orang dengan HIV dan AIDS (ODHA) di Yayasan Spirit Paramacitta.

Penelitian ini merupakan penelitian yang menggunakan pendekatan kuantitatif dengan metode korelasi. Sampel dalam penelitian berjumlah 76 orang yang dipilih dengan menggunakan teknik cluster sampling. Metode pengumpulan data dilakukan dengan menggunakan 2 buah skala, yakni skala dukungan sosial dan skala kualitas hidup. Analisis data yang digunakan yaitu analisis product moment dengan bantuan SPSS versi 17.0. Hasil analisis dari data penelitian menunjukkan nilai dari koefisien korelasi (r) sebesar 0,666 dengan angka signifikansi (p) sebesar 0,000 yang berarti bahwa terdapat hubungan yang positif antara dukungan sosial dengan kualitas hidup pada orang dengan HIV dan AIDS (ODHA) di Yayasan Spirit Paramacitta.
\end{abstract}

Kata kunci: dukungan sosial, kualitas hidup, ODHA

\begin{abstract}
The people who were infected by HIV would be very susceptible from illness, cause by the damage of the immune system. In the daily life, those people must be able to cope complex problems. Not only coping the physiological problems, but also coping the stigma and discrimination which can increase the psychological problems of people with HIV and AIDS. These complex problems will affect to the decrease of quality of life. One of the factor which has important role in quality of life is social support. Based on the background above, this research is aimed to determine the correlation between social support and quality of life on people with HIV and AIDS at Spirit Paramacitta Foundation.

This research was a quantitatif research with correlation method. The sample of this research were 76 people which were choosed by cluster sampling technique. Two kind of scales, there were social support scale and quality of life scale were used to gathered the data. The data were analyzed by correlation product moment with SPSS version 17.0. The research finding showed that the value of correlation coefficient (r) was 0,666 with the significance (p) 0,000 . It meant that there was a positif correlation between social support and quality of life on people with HIV and AIDS at Spirit Paramacitta Foundation.
\end{abstract}

Keywords: social support, quality of life, people with HIV and AIDS 


\section{LATAR BELAKANG}

Acquired Immunodeficiency Syndrome (AIDS) adalah sekumpulan gejala penyakit yang timbul karena rusaknya sistem kekebalan tubuh manusia akibat infeksi dari Human Immunodeficiency Virus (HIV), yaitu virus yang menyerang sistem kekebalan tubuh manusia (Departemen Kesehatan R.I., 2006). Bagi orang yang telah didiagnosa positif mengidap HIV dan AIDS sering disebut sebagai ODHA. Tuapattinaja (2004) menyebutkan bahwa ODHA adalah singkatan dari Orang Dengan HIV dan AIDS. ODHA merupakan pengganti dari istilah pengidap yang mengarah pada pengertian bahwa orang tersebut telah positif didiagnosa mengidap HIV dan AIDS.

Rusaknya sistem kekebalan tubuh pada orang yang terinfeksi HIV menyebabkan orang tersebut mudah diserang oleh penyakit-penyakit lain yang berakibat fatal dan sering disebut dengan infeksi oportunistik (Siregar, 2004). Greene, Derlega, Yep, dan Petronio (2003) menyebutkan bahwa penurunan sistem kekebalan tubuh dapat menyebabkan ODHA mengalami gejala-gejala menyerupai flu, seperti: lemas, mudah lelah, batuk yang berkepanjangan, demam, sakit kepala, nyeri otot, nafsu makan buruk, mual, pembengkakan kelenjar, berat badan yang durun drastik, dan bercak di kulit. Hal ini tentunya dapat menghambat ODHA untuk beraktivitas secara normal dalam kesehariannya.

Seperti yang dialami oleh Donna. Donna tidak pernah menyangka bahwa dirinya terinfeksi HIV. Ia awalnya merasa deman biasa yang dikiranya sebagai gejala tifus, namun ternyata deman yang ia alami tersebut tidak kunjung sembuh. Lama-kelamaan ternyata Donna merasa sulit makan dan lemas. Setiap Donna makan, ia selalu ingin muntah hingga akhirnya berat badan Donna pun mengalami penurunan secara drastis. Selama bulan Januari hingga Maret 2009, kondisi Donna semakin memburuk. Ia menjadi sering terkapar lemas di tempat tidur dan akhirnya mengalami kesulitan untuk melakukan aktivitas sehari-hari. Donna yang awalnya bekerja sebagai seorang staf marketing perusahaan swasta di Jakarta pun akhirnya memutuskan untuk berhenti bekerja, karena kondisinya yang semakin memburuk (Tabloid Gaya Hidup Sehat, 2010).

Hingga saat ini, jumlah ODHA di Bali telah mengalami lonjakan yang cukup tajam. Berdasarkan data yang diperoleh dari Komisi Penanggulangan AIDS (KPA) Kabupaten Gianyar, sudah terdapat 5.639 kasus HIV dan AIDS yang tercatat hingga tahun 2011. Penularan HIV di Bali ternyata mayoritas melalui hubungan seksual dengan rentang usia yang didominasi oleh golongan umur 20-29 tahun sebanyak 2.374 kasus. Golongan umur 30-39 tahun menduduki posisi kedua dengan jumlah pengidap sebanyak 2005 kasus dan disusul kemudian dengan golongan umur 4049 sebanyak 677 kasus. Berdasarkan data tersebut dapat disimpulkan bahwa pengidap HIV dan AIDS sebagian besar berada pada usia produktif. Hal ini juga terkait dengan perilaku beresiko yang memang lebih tinggi terjadi pada usia produktif.

Jumlah kasus di atas memberikan gambaran betapa penyakit tersebut sudah menjadi ancaman yang serius, khususnya di Pulau Bali. Apalagi hingga saat ini belum ada obat yang dapat menyembuhkan infeksi HIV dan AIDS itu sendiri. Walaupun infeksi HIV dan AIDS belum dapat disembuhkan, masih ada hal penting lain yang juga perlu diperhatikan oleh ODHA yaitu menjaga diri agar bisa meminimalisir segala hal yang bisa memperburuk keadaannya. Salah satu hal yang dapat memperburuk kondisi ODHA adalah adanya stigma dan diskriminasi yang berkembang di lingkungan masyarakat, tenaga medis, teman, maupun keluarga. Diskriminasi terjadi akibat masih kuatnya stigma di masyarakat yang menilai ODHA sebagai orang yang berperilaku menyimpang. Hal ini mengindikasikan bahwa masih minimnya pengetahuan yang dimiliki masyarakat terkait dengan HIV dan AIDS (Kompas, 2009).

Perlakuan diskriminasi terhadap ODHA, khususnya di Bali bisa dikatakan masih cukup tinggi. Seperti yang diberitakan pada harian Bali Post (2013) bahwa diskriminasi terhadap ODHA di Bali tidak hanya terjadi pada ODHA yang masih hidup saja, tetapi diskriminasi ini juga terjadi pada ODHA yang telah meninggal. Masyarakat masih banyak yang tidak mau memandikan jenazah ODHA, padahal memandikan jenazah merupakan bagian penting dari proses pemakaman di Bali. Kasus diskriminasi terhadap jenazah ODHA ini pernah terjadi di Gianyar. Ketika ada warga yang meninggal akibat terinfeksi HIV, warga yang lainnya tidak mau memandikan jenazah tersebut kerena takut tertular HIV. Jenazah akhirnya langsung dibawa ke kuburan untuk dimakamkan tanpa dibuka kembali. Perlakuan diskriminasi yang dilakukan oleh warga ternyata tidak hanya sampai disitu saja. Keluarga yang ditinggalkan juga dijauhi oleh warga, bahkan anak dari ODHA yang telah meninggal itu pun tidak diizinkan untuk bersekolah (Tempo, 2012).

AR yang merupakan salah satu ODHA di Bali juga pernah mengalami diskriminasi (Tabloid Galang Kangin, 2012). AR mendapatkan perlakuan diskriminasi dari keluarganya sendiri. AR menjadi sosok yang tersingkirkan dari keluarganya semenjak tahun 2002. Keluarga AR selalu membuang peralatan makan dan minum yang telah digunakan AR sebelumnya. Kamar AR pun dibuat terpisah dari rumah orang tua dan saudaranya. AR sangat sedih dan merasa tidak memiliki siapa-siapa lagi akibat dari perlakuan diskriminasi yang dilakukan oleh keluarganya sendiri.

Pemaparan beberapa kasus di atas telah mencerminkan bahwa stigma dan diskriminasi terhadap ODHA memang masih marak terjadi. Adanya stigma dapat memicu terjadinya diskriminasi yang berujung pada ketidaksetaraan dalam kehidupan sosial, sehingga ODHA 
enggan untuk membuka diri dan bersosialisasi di lingkungan sekitar. Seperti yang dipaparkan oleh Smetzer dan Bare (2002) bahwa ODHA memang sering mendapat stigma akibat dari virus yang menginfeksinya. ODHA sering disebut sebagai orang yang mengidap penyimpangan seksual atau gay, wanita nakal, dan salah pergaulan. Melalui stigma tersebut, ODHA kemudian dikucilkan dan tanpa disadari bahwa tindakan tersebut sebenarnya telah menambah beban psikologis dari ODHA itu sendiri.

ODHA dalam kesehariannya dituntut untuk mampu menghadapi permasalahan yang cukup kompleks. ODHA tidak hanya dihadapkan pada permasalahan dari sisi fisiologis akibat terinfeksi HIV, tetapi ODHA juga dihadapkan pada adanya stigma dan diskriminasi yang dapat menambah beban psikologis dari ODHA itu sendiri. Kompleksnya masalah yang mesti dihadapi oleh ODHA ini tentunya dapat berimbas pada penurunan kualitas hidup. Fayers dan Machin (2007) mengemukakan bahwa kualitas hidup sebagai pandangan atau perasaan seseorang terhadap kemampuan fungsionalnya akibat terserang oleh suatu penyakit. Kualitas hidup ini sangat berkaitan dengan hal-hal yang cukup kompleks seperti kesehatan fisik, kondisi psikologis, tingkat kemandirian, hubungan sosial, dan hubungan individu tersebut dengan lingkungannya (WHO, 2007).

ODHA memang semakin rentan terserang penyakitpenyakit lain akibat terinfeksi oleh HIV yang menyerang sistem kekebalan tubuh. Seperti yang telah dipaparkan dalam beberapa kasus sebelumnya bahwa beberapa ODHA menjadi lebih cepat lelah, mengalami demam yang tidak kunjung hilang, penurunan berat badan secara drastis hingga sering terkapar lemas di tempat tidur akibat dari infeksi HIV. Pada akhirnya mereka akan mengalami kesulitan dalam melakukan aktivitas sehari-hari bahkan mereka tidak mampu untuk bekerja lagi. Ketidakmampuan ODHA untuk melakukan aktivitas sehari-hari dan bahkan ketidakmampuan ODHA untuk bekerja ini telah mengindikasikan bahwa mereka mengalami penurunan kualitas hidup. Adanya stigma dan diskriminasi yang berujung pada ketidaksetaraan dalam kehidupan sosial yang membuat ODHA menjadi enggan untuk membuka diri dan bersosialisasi di lingkungan sekitar juga semakin menghambat ODHA untuk berfungsi dalam lingkungan sosialnya. Hal ini secara tidak langsung juga dapat sebagai pemicu penurunan kualitas hidup pada ODHA, sehingga diperlukan intervensi yang dapat membantu ODHA untuk menunjang kualitas hidupnya.

Nasronudin (2006) mengungkapkan bahwa salah satu faktor yang memiliki peranan penting dalam kualitas hidup ODHA adalah dukungan sosial. Dukungan sosial dapat diartikan sebagai suatu kenyamanan, perhatian, penghargaan, atau bantuan yang dirasakan individu dari orang lain atau kelompok lain (Uchino, 2004). Dengan adanya dukungan sosial ini maka seseorang akan merasa dihargai, dicintai, dan merasa menjadi bagian dari masyarakat, sehingga ODHA tidak merasa didiskriminasi yang nantinya dapat berdampak positif bagi kesehatannya (Sarafino, 2011).

Seperti pada kasus AR yang hampir enam tahun lebih berjuang agar diakui kembali di lingkungan keluarga dan masyarakat (Tabloid Galang Kangin, 2012). Berbagai cara ditempuh AR demi membina kembali hubungan baik dengan keluarga, misalnya dengan memberikan informasi dari artikel di internet, koran maupun majalah yang memuat berita mengembirakan mengenai ODHA. Lama-kelamaan AR akhirnya dapat menjalin komunikasi yang baik lagi dengan keluarganya, sehingga ia bisa mendapatkan dukungan dari keluarganya secara langsung. Dukungan yang diperoleh AR dari keluarganya ini telah mampu membuat AR lebih bersemangat dalam menjalani hidup. AR menjadi rajin untuk melakukan olahraga dan berusaha menjauhkan diri dari pola hidup yang buruk, misalnya dengan berhenti mengonsumsi obat-obatan terlarang. Hal ini menunjukkan bahwa dukungan sosial yang diterima AR telah mampu membuatnya untuk mengembangkan perilaku positif demi mencapai kehidupan yang lebih baik.

Berdasarkan uraian di atas, maka peneliti tertarik untuk meneliti mengenai hubungan antara dukungan sosial dengan kualitas hidup pada orang dengan HIV dan AIDS (ODHA) di Yayasan Spirit Paramacitta. Rumusan masalah dalam penelitian ini yaitu apakah terdapat hubungan antara dukungan sosial dengan kualitas hidup orang dengan HIV dan AIDS (ODHA) di Yayasan Spirit Paramacitta dengan tujuan penelitian untuk mengetahui hubungan antara dukungan sosial dengan kualitas hidup pada orang dengan HIV dan AIDS (ODHA) di Yayasan Spirit Paramacitta. Yayasan Spirit Paramacitta merupakan salah satu yayasan di Bali yang bergelut dalam bidang penanganan terhadap HIV dan AIDS. Yayasan Spirit Paramacitta ini merupakan sebuah organisasi yang lebih menitikberatkan pada peningkatan kualitas hidup ODHA dengan memberdayakan ODHA, sehingga mampu mencapai kemandirian dan kesejajaran di dalam kehidupan bermasyarakat (Yayasan Spirit Paramacitta, 2011).

Kegiatan-kegiatan yang dilakukan pihak yayasan demi mencapai kualitas hidup ODHA yang lebih baik, yaitu: 1. Memberikan informasi terkait dengan pelayanan kesehatan, dukungan emosional dan pendampingan bagi ODHA yang bermasalah dengan kesehatannya.

2. Memantau kepatuhan terapi pengobatan, khususnya terapi ARV.

3. Memberikan bantuan biaya terbatas pengobatan darurat melalui program Positive Fund.

4. Memberikan informasi dan pengetahuan mengenai pengetahuan dasar HIV dan AIDS, cara membuka status kesehatan kepada orang lain, pengobatan ARV dan perkembangan pengetahuan lain yang menunjang peningkatan kualitas hidup ODHA. 


\section{METODE PENELITIAN}

\section{Variabel dan definisi operasional}

Penelitian ini terdiri dari satu variabel bebas, yaitu dukungan sosial dan satu variabel tergantung, yaitu kualitas hidup dengan definisi operasional dari masing-masing variabel sebagai berikut:

1. Dukungan sosial merupakan suatu kenyamanan, perhatian, penghargaan, penerimaan, atau bantuan yang diperoleh ODHA dari individu atau kelompok lain. Dukungan sosial pada penelitian ini diukur dengan menggunakan skala dukungan sosial. Skala dukungan sosial terdiri dari 30 aitem dan disusun berdasarkan 5 aspek dukungan sosial, yaitu: dukungan emosional, dukungan harga diri, dukungan instrumental, dukungan informasinal, dan dukungan dari kelompok sosial.

2. Kualitas hidup merupakan keberfungsian ODHA secara fisik, spiritual, psikologis, dan sosial, sehingga dapat menjalankan aktivitas sehari-sehari dengan lebih optimal demi mencapai kehidupan yang ideal. Kualitas hidup pada penelitian ini diukur dengan menggunakan skala kualitas hidup. Skala kualitas hidup terdiri dari 30 aitem dan disusun berasarkan 3 dimensi kualitas hidup, yaitu: being, belonging dan becoming.

\section{Subjek Penelitian}

Keseluruhan dari subjek penelitian disebut dengan populasi (Nasution, 2003). Populasi dalam penelitian ini adalah seluruh ODHA di Yayasan Spirit Paramacitta yang berjumlah 95 orang. Mengingat adanya keterbatasan dana, waktu dan tempat dari peneliti, maka tidak memungkinkan bagi peneliti untuk melakukan pengambilan data pada seluruh individu dalam populasi. Keterbatasan inilah yang membuat peneliti untuk melakukan pengambilan sampel. Sesuai dengan tabel penentuan jumlah sampel yang dikembangkan oleh Isaac dan Michael (dalam Sugiyono, 2012) bahwa ukuran sampel yang harus dipenuhi dari ukuran populasi 95 orang dengan taraf kesalahan $5 \%$ adalah sebanyak 75 orang.

Metode pengambilan sampel dalam penelitian ini menggunakan metode probability sampling dengan teknik cluster sampling. Peneliti memilih menggunakan cluster sampling, sebab populasi dalam penelitian ini tersebar dalam beberapa kabupaten. Seperti yang diungkapkan oleh Usman dan Akbar (2011) bahwa cluster sampling cocok digunakan apabila populasi tersebar dalam beberapa daerah, provinsi, kabupaten, maupun kecamatan. Dari 90 skala yang disebarkan, hanya 76 skala yang berhasil dikumpulkan kembali oleh peneliti. Beberapa ODHA memang ada yang berhalangan hadir saat penelitian dengan alasan sakit atau ada anggota keluarganya yang sakit, mengikuti pelatihan dan ada pula yang bekerja.

\section{Tempat Penelitian}

Peneliti dalam penelitian ini menggunakan ODHA di Yayasan Spirit Paramacitta sebagai subjek penelitian dan ODHA di Yayasan Spirit Paramacitta tersebar dalam beberapa kabupaten di Bali, sehingga peneliti melakukan penelitian ke masing-masing kabupaten yang menjadi sampel penelitian. Rincian pelaksanaan pengambilan data pada masing-masing kabupaten secara rinci dapat dilihat pada tabel berikut:

Tabel 1. Tanggal Pelaksanaan Pengambilan Data

\begin{tabular}{clrc}
\hline No. & Kabupaten & Tanggal Pengambilan Data & Jumlah Subjek \\
\hline 1. & Bangli & 11 Februari 2013 & 6 \\
2. & Denpasar & 6 Februari 2013-14 Februari 2013 & 8 \\
3. & Jembrana & 14 Februari 2013 & 16 \\
4. & Gianyar & 14 Februari 2013 & 8 \\
5. & Karangasem & 17 Februari 2013 & 7 \\
6. & Tabanan & 20 Februari 2013 & 12 \\
7. & Singaraja & 25 Februari 2013-9 Maret 2013 & 19 \\
\hline \multicolumn{2}{c}{ Total } \\
\hline
\end{tabular}

Alat Ukur

Alat yang digunakan peneliti untuk memperoleh data dalam penelitian ini adalah skala psikologi. Azwar (2010) menyatakan bahwa skala psikologi dapat digunakan untuk mengungkap indikator-indikator perilaku dari atribut yang hendak diukur dengan menggunakan aitem-aitem pernyataan. Skala psikologi dalam penelitian ini terdiri dari pernyataan favorable dan pernyataan unfavorable. Pernyataan favorable menunjukkan indikator positif yang mendukung variabel yang diukur, sedangkan pernyataan unfavorable menunjukkan indikator negatif yang tidak mendukung variabel yang diukur. Peneliti dalam penelitian ini menggunakan 2 buah skala. Skala pertama merupakan skala yang mengukur dukungan sosial dan skala kedua adalah skala yang mengukur kualitas hidup pada orang dengan HIV dan AIDS (ODHA).

\section{Skala Dukungan Sosial}

Skala dukungan sosial disusun berdasarkan 5 aspek dukungan sosial yang diungkapkan oleh Sarafino (2011), yaitu dukungan emosional, dukungan harga diri, dukungan instrumental, dukungan informasional, dan dukungan dari kelompok sosial. Aitem dalam skala dukungan sosial berjumlah sebanyak 30 aitem. Sebaran aitem pada skala ini bisa dilihat pada tabel blue print yang telah disusun sebagai berikut:

Tabel 2. Blue Print Skala Dukungan Sosial

\begin{tabular}{clccc}
\hline \multirow{2}{*}{ No. } & \multicolumn{1}{|}{ Aspek } & \multicolumn{2}{c}{ Nomor aitem } & \multirow{2}{*}{ Jumlah } \\
\cline { 3 - 4 } & & Favorable & Unfavorable & \\
\hline 1. & Dukungan emosional & $1,15,30$ & $5,22,27$ & 6 \\
2. & Dukungan harga diri & $17,24,28$ & $2,9,12$ & 6 \\
3. & Dukungan instrumental & $4,8,26$ & $3,20,23$ & 6 \\
4. & Dukungan informasional & $14,25,29$ & 6 \\
5. & Dukungan dari kelompok sosial & $6,10,13$ & $7,16,21$ & 6 \\
\hline & Jumlah & $\mathbf{1 5}$ & $\mathbf{1 5}$ & $\mathbf{3 0}$ \\
\hline
\end{tabular}

Mengacu pada teori yang dikemukakan oleh Azwar (2010) bahwa nilai korelasi minimal sebesar 0,3 agar aitem dikatakan valid, maka terdapat 4 aitem yang gugur dari 30 aitem yang diujikan pada skala dukungan sosial. Uji validitas terhadap skala dukungan sosial dengan jumlah aitem sebanyak 26 aitem menghasilkan nilai koefisien korelasi yang bergerak dari 0,302 hingga 0,440. Pengujian lain yang dilakukan 
terhadap skala dukungan sosial adalah uji reliabilitas. Koefisien alpha yang diperoleh dari hasil uji reliabilitas terhadap skala dukungan sosial dengan jumlah aitem sebanyak 26 aitem adalah sebesar 0,826. Besarnya koefisien alpha yang melebihi 0,6 sesuai dengan yang diungkapkan oleh (Azwar, 2010) menandakan bahwa aitem dalam skala dukungan sosial ini reliabel.

\section{Skala Kualitas Hidup}

Skala kualitas hidup terdiri dari 30 aitem. Skala yang dibuat untuk mengukur kualitas hidup ini disusun berdasarkan 3 dimensi kualitas hidup yang diungkapkan oleh Raphael (dalam Philips, 2006 ), yaitu: being yang mencakup 3 aspek, yakni physical being, psychological being dan spiritual being. Dimensi kedua adalah belonging yang terdiri dari 3 aspek, yakni physical belonging, social belonging dan community belonging. Dimensi yang terakhir dari kualitas hidup adalah becoming yang mencakup 3 aspek, yaitu practical becoming, leisure becoming dan growth becoming. Sebaran aitem pada skala kualitas hidup bisa dilihat pada tabel blue print dibawah ini:

\begin{tabular}{|c|c|c|c|c|c|}
\hline \multirow{2}{*}{ No. } & \multirow{2}{*}{ Dimensi } & \multirow{2}{*}{ Aspek } & \multicolumn{2}{|c|}{ Nomor aitem } & \multirow{2}{*}{ Jumlah } \\
\hline & & & Favorable & Unfavorable & \\
\hline \multirow[t]{3}{*}{1.} & Being & physical being & 1,18 & 30 & 3 \\
\hline & & psychological being & 27 & 23,8 & 3 \\
\hline & & spiritual being & 13,24 & 3,12 & 4 \\
\hline \multirow[t]{3}{*}{2.} & Belonging & physical belonging & 11,15 & 19 & 3 \\
\hline & & social belonging & 4,7 & 28,14 & 4 \\
\hline & & community belonging & 9 & 21,26 & 3 \\
\hline \multirow[t]{4}{*}{3.} & Becoming & practical becoming & 20,29 & 5,17 & 4 \\
\hline & & leisure becoming & 6,10 & 25 & 3 \\
\hline & \multirow{2}{*}{\multicolumn{2}{|c|}{ Jumlah }} & 2 & 16,22 & 3 \\
\hline & & & 15 & 15 & 30 \\
\hline
\end{tabular}

Setelah melakukan uji validitas terhadap skala kualitas hidup, maka terdapat 3 aitem yang harus digugurkan dalam skala ini oleh karena memiliki nilai korelasi lebih kecil dari 0,3. Uji validitas terhadap skala kualitas hidup dengan jumlah aitem sebanyak 27 aitem menghasilkan nilai koefisien korelasi yang bergerak dari 0,305 hingga 0,477. Uji reliabilitas dengan koefisien alpha terhadap skala kualitas hidup dengan jumlah aitem sebanyak 27 aitem memperoleh hasil sebesar 0,844. Besarnya koefisien alpha yang lebih besar dari 0,6 mengindikasikan bahwa aitem dalam skala kualitas hidup ini reliabel.

\section{Metode pengumpulan data}

Peneliti dalam penelitian ini menggunakan 2 buah skala, yaitu skala dukungan sosial dan skala kualitas hidup. Tipe data yang diperoleh dari penentuan nilai respon pada penelitian ini adalah tipe data interval. Tipe data interval merupakan tipe data yang selain mempunyai ciri untuk membedakan dan mengurutkan pada rentang tertentu juga mempunyai ciri jarak yang sama dalam setiap urutannya (Boediono \& Koster, 2000). Teknik yang digunakan peneliti dalam proses menentukan nilai dari respon yang diberikan terhadap indikator dari variabel yang diukur adalah dengan mengacu pada teknik penskalaan Likert. Teknik penskalaan
Likert yang digunakan peneliti dalam penelitian ini hanya menggunakan empat alternatif jawaban, yaitu sangat setuju, setuju, tidak setuju, dan sangat tidak setuju. Skoring dari teknik penskalaan Likert yang digunakan dalam penelitian ini adalah sebagai berikut:

Tabel 4. Skoring Skala Likert

\begin{tabular}{ccc}
\hline Pernyataan Favorable & Skoring & Pernyataan Unfavorable \\
\hline Sangat setuju & 4 & Sangat tidak setuju \\
Setuju & 3 & Tidak setuju \\
Tidak setuju & 2 & Setuju \\
Sangat tidak setuju & 1 & Sangat setuju \\
\hline
\end{tabular}

\section{Metode Analisis Data}

Penelitian ini merupakan penelitian yang menggunakan pendekatan kuantitatif dengan metode korelasi. Silalahi (2012) mengemukakan bahwa penelitian dengan metode korelasi merupakan penelitian yang melihat hubungan antara variabel yang satu dengan variabel yang lainnya untuk memahami suatu fenomena dengan cara melihat tingkat hubungan di antara variabel-variabel tersebut. Nilai koefisien korelasi berkisar antara +1 sampai dengan -1 . Jika koefisien korelasi bernilai positif, maka kedua variabel mempunyai hubungan searah. Hubungan searah yang dimaksud disini mengindikasikan bahwa peningkatan atau penurunan skor di satu variabel, akan diikuti oleh peningkatan atau penurunan skor pada variabel lainnya. Jika koefisien korelasi bernilai negatif, maka kedua variabelnya memiliki hubungan yang tidak searah. Hubungan yang tidak searah ini mengindikasikan bahwa peningkatan skor pada satu variabel akan diikuti oleh penurunan skor pada variabel lainnya, atau sebaliknya jika terjadi penurunan skor pada satu variabel akan diikuti oleh penigkatan skor pada variabel lainnya.

Peneliti dalam penelitian ini memilih teknik korelasi product moment dari Pearson untuk menganalisis data penelitian. Hal ini didasarkan atas data penelitian dari masingmasing variabel yang berskala interval. Seperti yang diungkapkan oleh Usman dan Akbar (2011) bahwa korelasi product moment digunakan pada penelitian yang kedua variabelnya menggunakan skala interval. Asumsi lain yang juga harus dipenuhi agar dapat menggunakan teknik korelasi product moment ini adalah bahwa sebaran data penelitian haruslah berdistribusi normal.

Analisis korelasi juga dapat digunakan untuk menentukan sumbangan variabel independent terhadap variabel dependent. Besarnya sumbangan ini dapat dijelaskan dengan menggunakan koefisien determinasi. Koefisien determinasi diperoleh dengan mengkuadratkan nilai koefisien korelasi (Sugiyono, 2012). Analisis lain yang juga akan peneliti gunakan dalam penelitian ini adalah dengan melakukan perhitungan untuk menentukan kategori dari skor yang diperoleh masing-masing subjek penelitian menurut suatu kontinum berdasarkan atas atribut yang diukur. Cara 
pengkategorian skor pada penelitian ini mengacu pada rumus katerorisasi jenjang (ordinal) yang dikembangkan oleh Azwar (2010), yaitu:

Tabel 5. Rumus Kategori Skor

\begin{tabular}{cc}
\hline Skor & Kategorisasi \\
\hline $\mathrm{X} \leq(\mu-1,5 \sigma)$ & Sangat Rendah \\
$(\mu-1,5 \sigma)<\mathrm{X} \leq(\mu-0,5 \sigma)$ & Rendah \\
$(\mu-0,5 \sigma)<\mathrm{X} \leq(\mu+0,5 \sigma)$ & Sedang \\
$(\mu+0,5 \sigma)<\mathrm{X} \leq(\mu+1,5 \sigma)$ & Tinggi \\
$(\mu+1,5 \sigma)<\mathrm{X}$ & Sangat Tinggi \\
\hline Keterangan: & \\
$\mathrm{X} \quad:$ skor subjek penelitian & \\
$\mu \quad:$ mean teoritis & \\
$\sigma \quad:$ standar deviasi &
\end{tabular}

Mean teoritis merupakan rata-rata skor penelitian. Mean teoritis diperoleh dengan menjumlahkan skor terendah dengan skor tertinggi dari sebuah skala dan hasil penjumlahan ini kemudian dibagi 2 ((X $\min +X \max ): 2)$. Standar deviasi yang sering disebut dengan simpangan baku digunakan untuk melihat variasi sebaran data. Standar deviasi ini diperoleh dengan cara mencari range dari skor skala yang digunakan dan hasilnya kemudian dibagi 6 . Range adalah selisih dari skor tertinggi dengan skor terendah dari skala (X max - Xmin).

\section{HASIL PENELITIAN}

Penelitian ini menggunakan pendekatan kuantitatif dengan metode korelasional. Sebelum melakukan analisa terhadap data penelitian, terlebih dahulu perlu dilakukan uji asumsi terhadap data penelitian. Uji asumsi yang patut dilakukan dalam penelitian yang menggunakan metode korelasional meliputi uji normalitas dan uji linearitas.

a. Uji Normalitas

Uji normalitas dilakukan untuk mengetahui apakah sebaran data pada variabel dukungan sosial maupun kualitas hidup terdistribusi normal atau tidak (Sugiyono, 2012). Uji normalitas ini penting dilakukan, karena data yang terdistribusi secara normal merupakan persyaratan yang harus dipenuhi untuk melakukan pengujian hipotesis dengan metode statistik parametrik. Korelasi product moment merupakan salah satu bagian dari teknik analisis data dalam statistik parametrik, sehingga uji normalitas ini wajib untuk dilakukan terhadap data dalam penelitian ini.

Trihendradi (2008) menyatakan bahwa data yang terdistribusi normal adalah data yang memiliki nilai signifikansi lebih dari 0,05 ( $\mathrm{p}>0,05)$. Hasil uji normalitas terhadap data pada variabel dukungan sosial menunjukkan nilai signifikansi 0.588 . Nilai signifikansi ini lebih besar dari nilai signifikansi standar yaitu 0.05, sehingga dapat dikatakan bahwa sebaran data pada variabel dukungan sosial terdistribusi normal. Sebaran data pada variabel kualitas hidup juga terdistribusi normal. Hal tersebut dapat dilihat dari besarnya nilai signifikansi variabel kualitas hidup sebesar 0.695 yang nilainya juga lebih besar dari 0.05. Jadi, dapat disimpulkan bahwa kedua variabel dalam penelitian ini berdistribusi normal.

b. Uji Linearitas

Uji linearitas digunakan untuk mengetahui apakah distribusi data penelitian memiliki hubungan linear atau tidak. Hubungan kedua variabel dinyatakan linear ketika nilai $\mathrm{p}<$ 0,05 , sebaliknya jika $\mathrm{p}>0,05$ maka hubungan antara kedua variabel penelitian dinyatakan tidak linear (Trihendradi, 2008). Hasil uji linearitas terhadap variabel dukungan sosial dengan variabel kualitas hidup menunjukkan hubungan yang linear. Hal tersebut ditunjukkan dengan nilai probabilitas (p) sebesar 0,000 yang nilainya lebih kecil dari 0,05.

Berdasarkan kedua uji asumsi yang menjadi syarat untuk dapat menggunakan metode analisis korelasi product moment, diperoleh hasil bahwa data dalam penelitian ini terdistribusi normal dan memiliki hubungan yang linear. Hal ini mengindikasikan bahwa analisis data dalam penelitian ini dapat dilanjutkan dengan mengunakan teknik korelasi product moment. Analisis data dalam penelitian ini dilakukan dengan bantuan program SPSS versi 17.0 for windows dengan hasil sebagai berikut:

Tabel 6. Hasil Analisis Korelasi

\begin{tabular}{ccrr}
\hline & & $\begin{array}{c}\text { Dukungan } \\
\text { Sosial }\end{array}$ & $\begin{array}{c}\text { Kualitas } \\
\text { Hidup }\end{array}$ \\
\hline Dukungan Sosial & Pearson Correlation & 1 & $.666^{* *}$ \\
& Sig. (1-tailed) & & .000 \\
Kualitas Hidup & Pearson Correlation & $.666^{* * *}$ & 76 \\
& Sig. (1-tailed) & .000 & 1 \\
& $\mathrm{~N}$ & 76 & 76 \\
\hline
\end{tabular}

Hasil pengolahan data di atas menunjukkan bahwa nilai koefisien korelasi sebesar 0,666. Angka korelasi ini menunjukkan bahwa hubungan antara dukungan sosial dengan kualitas hidup bersifat positif yang mengindikasikan bahwa semakin tinggi dukungan sosial, maka semakin tinggi pula kualitas hidup pada subjek penelitian. Besarnya sumbangan variabel dukungan sosial terhadap variabel kualitas hidup juga dapat dijelaskan melalui analisis korelasi dengan menggunakan koefisien determinasi (r2). Koefisien determinasi dalam penelitian ini dengan nilai koefisien korelasi sebesar 0,666 adalah 0,444. Koefisien determinasi sebesar 0,444 menandakan bahwa sumbangan variabel dukungan sosial terhadap variabel kualitas hidup sebesar 44,4\% dan sisanya sebesar 55,6\% ditentukan oleh faktorfaktor lain yang tidak diteliti dalam penelitian ini.

Hasil uji korelasi antara variabel dukungan sosial dengan variabel kualitas hidup menunjukkan angka signifikansi (p) sebesar 0,000. Angka signifikansi ini memiliki nilai yang lebih kecil dari 0,05 dan sesuai dengan kaidah yang telah ditentukan bahwa jika angka signifikansi hasil penelitian $<0,05$, maka H0 ditolak dan Ha diterima. Hal ini menandakan bahwa ada hubungan positif antara dukungan sosial dengan 
kualitas hidup pada orang dengan HIV dan AIDS (ODHA) di Yayasan Spirit Paramacitta.

Analisis lain yang juga peneliti gunakan dalam penelitian ini adalah dengan melakukan perhitungan untuk menentukan kategori skor yang diperoleh masing-masing subjek penelitian menurut suatu kontinum berdasarkan atas atribut yang diukur. Hasil perhitungan kategori subjek dalam penelitian ini adalah sebagai berikut:

1. Kategorisasi Subjek pada Skala Dukungan Sosial

Hasil kategorisasi subjek pada skala dukungan sosial menunjukkan bahwa sebagian besar ODHA memiliki dukungan sosial yang sangat tinggi, yaitu sebanyak 44 orang atau sebesar 58\%. Sebanyak 32 ODHA termasuk dalam kategori dengan tingkat dukungan sosial yang tinggi atau sebesar $42 \%$. Hasil kategorisasi subjek pada skala dukungan sosial secara rinci dapat dilihat pada tabel berikut:

Tabel 7. Kategorisasi Subjek pada Skala Dukungan Sosial

\begin{tabular}{ccccc}
\hline Variabel & Rentang Nilai & Kategori & Subjek & Persentase \\
\hline & $\mathrm{X} \leq 45,5$ & Sangat Rendah & 0 orang & $0 \%$ \\
Dukungan & $45,5 \leq \mathrm{X} \leq 63,7$ & Rendah & 0 orang & $0 \%$ \\
Sosial & $63,7 \leq \mathrm{X} \leq 66,3$ & Sedang & 0orang & $0 \%$ \\
& $66,3 \leq \mathrm{X} \leq 84,5$ & Tinggi & 32 orang & $42 \%$ \\
& $84,5<\mathrm{X}$ & Sangat Tinggi & 44 orang & $58 \%$ \\
\hline & Jumlah & & 76 orang & $100 \%$ \\
\hline
\end{tabular}

2.

Kategorisasi Subjek pada Skala Kualitas Hidup

Hasil kategorisasi pada skala kualitas hidup menunjukkan hasil bahwa terdapat 8 orang ODHA yang termasuk dalam kategori kualitas hidup sedang atau sebesar 11\%. Jumlah ODHA yang berada dalam kategori kualitas hidup tinggi adalah sebanyak 45 orang atau sebesar $59 \%$. Sebanyak 23 ODHA lainnya ternyata masuk dalam kategori dengan kualitas hidup sangat tinggi yang jika dipersentasekan sebesar 30\%. Hasil kategorisasi pada skala kualitas hidup secara rinci dapat dilihat pada tabel di bawah ini.

\begin{tabular}{|c|c|c|c|c|}
\hline Variabel & Rentang Nilai & Kategori & Subyek & Persentase \\
\hline & $\mathrm{X} \leq 47,25$ & Sangat Rendah & 0 orang & $0 \%$ \\
\hline Kualitas & $47,25 \leq X \leq 60,75$ & Rendah & 0 orang & $0 \%$ \\
\hline \multirow[t]{4}{*}{ Hidup } & $60,75 \leq X \leq 74,25$ & Sedang & 8 orang & $11 \%$ \\
\hline & $74,25 \leq \mathrm{X} \leq 87,75$ & Tinggi & 45 orang & $59 \%$ \\
\hline & $87,75<\mathrm{X}$ & Sangat Tinggi & 23 orang & $30 \%$ \\
\hline & Jumlah & & 76 orang & $100 \%$ \\
\hline
\end{tabular}

\section{PEMBAHASAN DAN KESIMPULAN}

Nilai koefisien korelasi berdasarkan analisis yang dilakukan melalui teknik korelasi product moment dari Pearson adalah sebesar 0,666 dengan angka signifikansi 0,000 ( $\mathrm{p}<0,05$ ). Nilai ini menunjukkan bahwa terdapat hubungan positif antara variabel dukungan sosial dengan variabel kualitas hidup. Hubungan positif ini memiliki arti bahwa semakin tinggi dukungan sosial, maka semakin tinggi pula kualitas hidup pada subjek penelitian.

Angka signifikansi pada penelitian ini memiliki nilai yang lebih kecil dari 0,05 dan sesuai dengan kaidah yang telah ditentukan bahwa jika angka signifikansi hasil penelitian <
0,05, maka H0 ditolak dan Ha diterima. Hal ini menandakan bahwa ada hubungan positif antara dukungan sosial dengan kualitas hidup pada orang dengan HIV dan AIDS (ODHA) di Yayasan Spirit Paramacitta. Hasil penelitian ini sejalan dengan hasil penelitian yang dilakukan oleh Tuapattinaja (2004) bahwa dukungan sosial yang diterima ODHA mampu meredakan kecemasan atau kondisi stres yang muncul terkait dengan sakit yang diidapnya, sehingga ODHA menjadi lebih tenang dan mampu mengarah pada kualitas hidup yang lebih baik.

Kualitas hidup merupakan kemampuan individu dalam menikmati kepuasan selama hidupnya (Ventegodt, Merrick dan Andersen, 2003). Individu harus mampu berfungsi secara fisik, spiritual, psikologis, dan sosial demi mencapai kualitas hidup yang baik. Kualitas hidup pada ODHA itu sendiri memang cukup rentan untuk mengalami penurunan akibat adanya masalah secara fisiologis, maupun masalah secara psikologisnya. ODHA menjadi sangat rentan terserang penyakit akibat terinfeksi HIV yang merusak sistem kekebalan tubuh. Penurunan sistem kekebalan tubuh ini akan menyebabkan ODHA mengalami gejala-gejala menyerupai flu, seperti: lemas, batuk yang berkepanjangan, demam, sakit kepala, nyeri otot, nafsu makan buruk, mual, pembengkakan kelenjar, dan bercak di kulit (Greene, Derlega, Yep, \& Petronio, 2003). Tidak jarang bahwa ODHA mengalami penurunan berat badan secara drastis hingga sering terkapar lemas ditempat tidur akibat dari infeksi HIV. ODHA akhirnya akan mengalami kesulitan untuk melakukan aktivitas seharihari, bahkan mereka tidak mampu untuk bekerja lagi. Ketidakmampuan ODHA untuk melakukan aktivitas seharihari dan bahkan ketidakmampuan untuk bekerja telah mengindikasikan bahwa ODHA mengalami penurunan kualitas hidup.

ODHA sebenarnya tidak hanya mengalami tekanan akibat adanya virus HIV yang menyerang sistem kekebalan tubuh saja, tetapi ODHA juga dihadapkan pada stigma dan diskriminasi. Sesuai dengan yang diungkapkan oleh Smetzer dan Bare (2002) bahwa ODHA sering mendapat stigma akibat dari virus yang menginfeksinya. ODHA sering disebut sebagai orang yang mengidap penyimpangan seksual atau gay, wanita nakal, dan salah pergaulan. Melalui stigma tersebut, ODHA kemudian dikucilkan dan tanpa disadari bahwa tindakan tersebut sebenarnya telah mempengaruhi kondisi psikologis ODHA. Hal ini mengantarkan ODHA pada kondisi stres, depresi, putus asa dan menutup diri. ODHA akan memilih untuk merahasiakan status kesehatannya dari keluarga, teman maupun kerabat dekatnya, sehingga ODHA pun tidak mampu mendapatkan dukungan yang seharusnya diperoleh (Gunung, Sumantera, Sawitri, \& Wirawan, 2002).

ODHA sebenarnya membutuhkan dukungan, bukan dikucilkan agar harapan hidup ODHA menjadi lebih panjang. Sarafino (2011) mengungkapkan bahwa dengan adanya 
dukungan sosial maka akan tercipta lingkungan kondusif yang mampu memberikan motivasi maupun memberikan wawasan baru bagi ODHA dalam menghadapi kehidupannya. Dukungan sosial ini dapat meminimalkan tekanan psikososial yang dirasakan ODHA, sehingga ODHA dapat memiliki gaya hidup yang lebih baik dan dapat memberikan respon yang lebih positif terhadap lingkungan sosialnya. Selain itu, dengan adanya dukungan sosial ini maka ODHA akan merasa dihargai, dicintai, dan merasa menjadi bagian dari masyarakat, sehingga ODHA tidak merasa didiskriminasi yang nantinya dapat bedampak positif bagi kesehatannya.

Peneliti dalam penelitian ini menggunakan koefisien determinasi (r2) untuk mengetahui besarnya sumbangan variabel dukungan sosial terhadap variabel kualitas hidup pada ODHA. Nilai koefisien determinasi yang diperoleh nilai koefisien korelasi (r) sebesar 0,666 adalah 0,444. Koefisien determinasi sebesar 0,444 menunjukkankan bahwa sumbangan variabel dukungan sosial terhadap variabel kualitas hidup sebesar $44,4 \%$ dan sisanya sebesar $55,6 \%$ ditentukan oleh faktor-faktor lain yang tidak diteliti dalam penelitian ini, seperti: kepadatan HIV di dalam tubuh, respon imun, penggunaan ARV, faktor psikososial, manajemen stres, dan spiritual.

Analisis lain yang juga peneliti gunakan dalam penelitian ini adalah dengan melakukan perhitungan untuk menentukan kategori dari skor yang diperoleh masing-masing subjek penelitian menurut suatu kontinum berdasarkan atas atribut yang diukur. Subjek dalam penelitian ini merupakan ODHA yang terdaftar di Yayasan Spirit Paramacitta. Yayasan Spirit Paramacitta ini merupakan sebuah organisasi yang lebih menitikberatkan pada peningkatan kualitas hidup ODHA dengan memberdayakan ODHA, sehingga mampu mencapai kemandirian dan kesejajaran di dalam kehidupan bermasyarakat (Yayasan Spirit Paramacitta, 2011).

Kegiatan-kegiatan yang dilakukan pihak yayasan demi mencapai kualitas hidup ODHA yang lebih baik, yaitu:

1. Memberikan informasi terkait dengan pelayanan kesehatan, dukungan emosional dan pendampingan bagi ODHA yang bermasalah dengan kesehatannya. Pihak yayasan berusaha untuk membantu ODHA mendapatkan akses pelayanan kesehatan yang memadai. Bagi ODHA yang belum mengetahui cara mendapatkan akses pelayanan kesehatan, pihak yayasan akan memberitahukan kepada ODHA tersebut mengenai alur yang harus ditempuh demi mendapatkan pelayanan kesehatan dan secara tidak langsung bantuan yang diberikan pihak yayasan ini juga membuka jalan bagi ODHA untuk mendapatkan dukungan berupa pelayanan kesehatan yang memadai dari pihak medis. Dukungan yang diberikan pihak yayasan pun tidak sebatas pada pembukaan akses layanan kesehatan, tetapi pihak yayasan juga berusaha untuk memberikan dukungan emosional kepada ODHA agar bisa bangkit dari keterpurukannya, sehingga tidak memperburuk kondisi sakit dari ODHA itu sendiri.

2. Memantau kepatuhan terapi pengobatan, khususnya terapi ARV. ARV merupakan obat yang sangat penting dikonsumsi ODHA untuk menekan jumlah HIV di dalam tubuh, sehingga pihak yayasan pun selalu mewanti-wanti agar ODHA tidak sampai putus obat agar kondisinya tidak meburuk. Apalagi sekarang semakin banyak pengobatan alternatif yang dikatakan mampu menyembuhkan HIV dan AIDS, sehingga pihak yayasan pun harus semakin gencar untuk meyakinkan ODHA agar tetap mengonsumsi ARV dan tidak mudah terpengaruh dengan pengobatan alternatif. Pihak yayasan juga meminta agar ODHA yang satu dengan yang lainnya bisa saling mengingatkan agar tetap rutin meminum obat dan saling membantu jika memang ada ODHA yang kehabisan obat dengan bersedia memberikan pinjaman obat yang sesuai dengan kebutuhan obat dari ODHA tersebut.

3. Memberikan bantuan biaya terbatas pengobatan darurat melalui program Positive Fund. Pihak yayasan juga bersedia memberikan bantuan biaya terbatas kepada ODHA yang dalam berada kondisi darurat dan mengalami kesulitan dalam keuangan agar ODHA tersebut bisa mendapatkan pelayanan kesehatan yang lebih memadai.

4. Memberikan informasi dan pengetahuan mengenai pengetahuan dasar HIV dan AIDS, cara membuka status kesehatan kepada orang lain, pengobatan ARV dan perkembangan pengetahuan lain yang menunjang peningkatan kualitas hidup ODHA. Pihak yayasan melakukan pertemuan secara rutin dengan ODHA setiap satu bulan sekali untuk memberikan informasi dan pengetahuan baru terkait HIV dan AIDS. Melalui pertemuan rutin ini, pihak yayasan juga mengajak ODHA untuk berdiskusi terkait permasalahan yang sering dihadapi ODHA, misalnya kesulitan ODHA untuk bisa membuka status kepada keluarga. Pihak yayasan pun akan berusaha memberikan tips-tips yang dapat membantu ODHA agar bisa membuka status kesehatannya tersebut serta menanyakan kembali tips-tips lain kepada ODHA yang telah bisa membuka statusnya kepada keluarga. Keterbukaan ODHA mengenai status kesehatannya kepada keluarga maupun orang terdekat merupakan hal penting bagi pihak yayasan agar ODHA tersebut bisa mendapatkan lebih banyak dukungan yang nantinya dapat menunjang kesehatan ODHA itu sendiri.

Keempat kegiatan yang dilakukan pihak Yayasan Spirit Paramacitta ini dapat dikatakan sebagai kegiatan yang mencerminkan dukungan dari pihak yayasan terhadap ODHA yang secara tidak langsung juga membuka akses bagi ODHA untuk mendapatkan dukungan dari tenaga medis, teman, dan keluarga. Tingkat dari dukungan sosial dan kualitas hidup ODHA di Yayasan Spirit Paramacitta dapat dilihat dari hasil kategorisasi ODHA pada skala dukungan sosial dan kualitas hidup. Hasil kategorisasi ODHA pada skala dukungan sosial 
menunjukkan bahwa sebagian besar ODHA memiliki dukungan sosial yang sangat tinggi, yaitu sebanyak 44 orang atau sebesar 58\%. Sebanyak 32 ODHA termasuk dalam kategori dengan tingkat dukungan sosial yang tinggi atau sebesar $42 \%$.

Hasil kategorisasi ODHA pada skala kualitas hidup menunjukkan hasil bahwa terdapat 8 ODHA yang termasuk dalam kategori kualitas hidup sedang atau sebesar $11 \%$. ODHA yang menjadi subjek dalam penelitian ini ternyata lebih banyak masuk dalam kategori kualitas hidup tinggi. ODHA yang berada dalam kategori ini sebanyak 45 orang atau sebesar 59\%. Sebanyak 23 ODHA lainnya ternyata masuk dalam kategori dengan kualitas hidup sangat tinggi yang jika dipersentasekan sebesar 30\%.

Peneliti dalam penelitian ini telah melalui prosedur penelitian dan telah melakukan analisis data sesuai dengan kaidah yang ditentukan, sehingga peneliti mampu membuktikan bahwa hipotesis nol (H0) dalam penelitian ini ditolak dan menerima hipotesis alternatif (Ha) yang menandakan bahwa ada hubungan positif antara dukungan sosial dengan kualitas hidup pada orang dengan HIV dan AIDS (ODHA) di Yayasan Spirit Paramacitta. Berdasarkan hasil kategorisasi dapat disimpulkan bahwa sebagian besar ODHA telah memperoleh dukungan sosial yang sangat tinggi dengan persentase 58\% dan sebagian besar ODHA juga telah memiliki kualitas hidup yang tinggi dengan persentase $59 \%$. Nilai dari koefisien determinasi sebesar 0,444 menandakan bahwa sumbangan efektif dari variabel dukungan sosial terhadap variabel kualitas hidup sebesar $44,4 \%$ dan sisanya sebesar 55,6\% ditentukan oleh faktor-faktor lain yang tidak diteliti dalam penelitian ini, seperti: kepadatan HIV di dalam tubuh, respon imun, penggunaan ARV, faktor psikososial, manajemen stres, dan spiritual.

Berdasarkan hasil penelitian yang diperoleh mengenai hubungan antara dukungan sosial dengan kualitas hidup pada orang dengan HIV dan AIDS (ODHA) di Yayasan Spirit Paramacitta, maka saran yang dapat diberikan oleh peneliti antara lain:

1. Saran Praktis

a. Bagi orang dengan HIV dan AIDS (ODHA)

Hasil kategorisasi skor pada skala kualitas hidup memang telah menunjukkan bahwa ODHA memiliki kualitas hidup yang berada dalam kategori, yaitu sedang, tinggi dan sangat tinggi, namun meskipun demikian ODHA diharapkan untuk tetap berusaha meminimalisir segala hal yang bisa memperburuk kesehatannya, misalnya dengan menjaga asupan nutrisi yang baik bagi tubuh, melakukan olahraga secara rutin, lebih mendekatkan diri kepada Tuhan dan melakukan manajemen stres dengan belajar berpikir positif maupun dengan melakukan hal-hal yang digemari demi mengurangi stres itu sendiri.

b. Bagi Yayasan Spirit Paramacitta
Pihak yayasan dapat memanfaatkan hasil penelitian ini untuk mengevaluasi program-program yang telah dilakukan, sehingga nantinya pihak yayasan dapat mengembangkan program-program baru yang lebih inovatif dan kreatif demi menunjang peningkatan kualitas hidup ODHA, misalnya dengan melakukan olahraga secara bersama. Pihak yayasan juga diharapkan dapat mensosialisasikan mengenai HIV dan AIDS kepada mayarakat maupun tenaga medis demi meminimalisir adanya stigma dan diskriminasi terhadap ODHA.

\section{c. Bagi Tenaga Medis}

Tenaga medis hendaknya dapat memberikan dukungan secara optimal terhadap ODHA, khususnya berupa pelayanan kesehatan yang memadai demi membantu ODHA dalam mencapai kualitas hidup yang lebih baik tanpa melakukan stigma maupun diskriminasi terhadap ODHA. Tenaga medis juga diharapkan dapat membantu meminimalisir stigma dan diskriminasi yang berkembang di masyarakat dengan mensosialisasikan pentingnya perawatan terhadap ODHA, baik dari kesehatan fisik mapun psikologisnya demi meringankan beban dari sakit yang diidapnya.

\section{d. Bagi Pemerintah}

Pemerintah diharapkan lebih mengoptimalkan sosialisasi mengenai pentingnya dukungan sosial terhadap ODHA dengan menggunakan berbagai media promosi yang tersedia, misalnya majalah, surat kabar, televisi, maupun internet. Pemerintah sebaiknya juga memperbanyak kaderkader di masyarakat yang peduli terhadap HIV dan AIDS agar sosialisasi mengenai HIV dan AIDS dapat diberikan secara utuh dan menyeluruh.

\section{e. Bagi Masyarakat}

Masyarakat bisa menggunakan bantuan dari media elektronik maupun media massa untuk mendapatkan informasi yang utuh dan menyeluruh mengenai HIV dan AIDS, sehingga bisa meningkatkan kepedulian terhadap ODHA tanpa melakukan diskriminasi. Masyarakat diharapkan agar bisa lebih empati terhadap ODHA, sehingga masyarakat bisa memberikan dukungan sosial demi pencapaian kualitas hidup ODHA yang lebih baik.

2. Saran Bagi Peneliti Selanjutnya

a. Nilai koefisien determinasi dari data penelitian ini adalah sebesar 0,444 yang menandakan bahwa sumbangan efektif dari variabel dukungan sosial terhadap variabel kualitas hidup sebesar $44,4 \%$ dan sisanya sebesar $55,6 \%$ ditentukan oleh faktor-faktor lain yang tidak diteliti dalam penelitian ini. Mengacu pada hal tersebut, maka peneliti menyarankan kepada peneliti selanjutnya agar meneliti topik lain yang berkaitan dengan kualitas hidup ODHA, misalnya dengan mengkaji faktor lain yang dapat mempengaruhi kualitas hidup ODHA, seperti kepadatan HIV di dalam tubuh, respon imun, 
penggunaan ARV, faktor psikososial, manajemen stres, dan spiritual.

b. Jika peneliti selanjutnya berkeinginan untuk meneliti topik yang sama, diharapkan agar peneliti tersebut bisa mengkhususkan sumber dari dukungan sosial yang diperoleh dari ODHA, misalnya dukungan sosial dari keluarga, teman sebaya, tenaga medis, atau LSM. Peneliti selanjutkan juga diharapkan dapat melakukan penelitian mengenai kaitan antara dukungan sosial dengan kualitas hidup ODHA dengan mix method, regresi, maupun dengan korelasi parsial, sehingga hasil penelitian yang didapatkan lebih mendalam.

\section{DAFTAR PUSTAKA}

Azwar, S. (2010). Reliabilitas dan validitas. Yogyakarta: Pustaka Pelajar.

Boediono, \& Koster. (2004). Teori dan aplikasi statistika dan probabilitas. Bandung: PT Remaja Rosdakarya.

Departemen Kesehatan. (2006). Situasi HIV/AIDS di Indonesia tahun 1987-2006. Retrieved from http://www.depkes.go.id/downloads/publikasi/Situasi\%20HIVAIDS\%202006.pdf

Djamilahnajmuddin. (2010, April). Optimisme HIV lenyap dari tubuhnya. Tabloid Gaya Hidup Sehat. Retrieved from http://www.djamilah-najmuddin.com/optimis-hiv-lenyap-daritubuhnya-sebuah-kisah-dari-pasien-hiv

Fayers, M., \& Machin. (2007). Quality of life (2nd ed.). England: John Wiley \&Sons Ltd.

Greene, Derlega V. J., Yep, \& Petronio S. (2003). Privacy and disclosure of HIV in interpersonal relationship. London: Lawrence Erlbaum Associates.

Gunung, Sumantera, Sawitri, \& Wirawan. (2002). Buku pengangan HIV/AIDS. Denpasar: Yayasan Kerti Praja.

Hasan, Rofiqi. (2012, Januari). Bali diskriminatif terhadap penderita HIV AIDS. Tempo. Retrieved from: http://www.tempo.co/read/news/2012/01/11/058376704/

Jenazah penderita HIV setelah empat jam tidak menularkan virus. (2013, April). Bali Post. Retrieved from http://www.balipost.co.id/mediadetail.php?module=detailberita minggu\&kid $=24 \& i d=75204$

Komisi Penanggulangan AIDS. (2012). Data AIDS. Gianyar: KPA.

Nasronudin. (2006). HIV dan AIDS: Pendekatan biologi molekuler, klinis dan sosial. Surabaya: Airlangga University Press.

Nasution.(2003). Teknik sampling. Sumatera: Universitas Sumatra Utara Press.

Phillips, D. (2006). Quality of life: Concept, policy and practice. London: Routledge.

Sarafino E. (2011). Health psychology: Biopsychosocial interactions (7th ed). Canada: John Wiley \& Sons, Inc.

Silalahi. (2012). Metode penelitian sosial. Bandung: Refika Aditama.

Siregar A. (2004). Pengenalan dan pencegahan AIDS. Sumatra: Universitas Sumatra Utara Press.

Smetzer \& Bare. (2001). Buku ajar keperawatan medikal-bedah (8th ed.). Jakarta: Buku Kedokteran EGC.

Stigma dan perlakuan yang menyakitkan. (2009, Desember). Kompas.

Retrieved
http://internasional.kompas.com/read/2009/12/02/05301215/Stig ma.dan.Perlakuan.yang.Menyakitkan.Itu.

Suara ODHA menolak diskriminasi. (2012, November). Tabloid Galang Kangin, 11. Retrieved from: http://etabloidgalangkangin2.blogspot.com/2012/11/suara-odhamenolak-diskriminasi-edisi.html

Sugiyono. (2012). Statistika untuk penelitian. Bandung: Alfabeta.

Trihendradadi C. (2008). Step by step SPSS 16: Analisis data statistik. Yogyakarta: ANDI.

Tuapattinaja. (2004). Gambaran Dukungan Sosial Pada ODHA(Orang Dengan HIV/AIDS). Retrieved fromhttp://repository.usu.ac.id/handle/123456789/7154

Uchino, B. N. (2004). Social support and physical health: Understanding the health consequences of relationship. New Haven: Yale University Press.

Usman \& Akbar. (2011). Pengantar satistika.Jakarta: Bumi Aksara.

Ventegodt, Merrick \& Andersen. (2003). Quality od life theory I. the IQOL theory: An Integrative theory of the global quality of life concept. The Scientific World Journal, 3, 1030-1040.

World Health Organization. (2007, Mei). Retrieved from: http://www.who.int/en/

Yayasan Spirit Paramacitta. (2011). Retrieved from: http://spiritparamacitta.wordpress.com/ 